\title{
Biomass fly ashes as low-cost chemical agents for Pb removal from synthetic and industrial wastewaters
}

\author{
Rui Barbosa ${ }^{a, *}$, Nuno Lapa ${ }^{a}$, Helena Lopes ${ }^{b}$, Annika Günther ${ }^{c}$, Diogo Dias $^{a}$, Benilde Mendes ${ }^{a}$ \\ a Universidade Nova de Lisboa, Faculdade de Ciências e Tecnologia, Departamento de Ciências e Tecnologia da Biomassa, Campus da Caparica, Ed. Departamental, Piso 3, gab. \\ 377, 2829-516 Caparica, Portugal

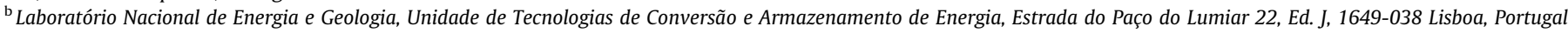 \\ ${ }^{\mathrm{c}}$ Dresden University of Technology, Faculty of Environmental Sciences, Institute of Hydrology and Meteorology, 01062 Dresden, Germany
}

\section{A R T I C L E I N F O}

\section{Article history:}

Received 11 December 2013

Accepted 1 March 2014

Available online 12 March 2014

\section{Keywords:}

Biomass fly ashes

Ecotoxicity

Industrial wastewaters

Lead-acid batteries

$\mathrm{Pb}$

\begin{abstract}
A B S T R A C T
The main aim of this work was to study the removal efficiency of $\mathrm{Pb}$ from synthetic and industrial wastewaters by using biomass fly ashes. The biomass fly ashes were produced in a biomass boiler of a pulp and paper industry. Three concentrations of $\mathrm{Pb}^{2+}$ were tested in the synthetic wastewater $(1,10$ and $1000 \mathrm{mg}$ $\mathrm{Pb} / \mathrm{L}$ ). Moreover, two different wastewaters were collected in an industrial wastewater treatment plant (IWWTP) of an industry of lead-acid batteries: (i) wastewater of the equalization tank, and (ii) IWWTP effluent. All the wastewaters were submitted to coagulation-flocculation tests with a wide range of biomass fly ashes dosage (expressed as Solid/Liquid - S/L - ratios). All supernatants were characterized for chemical and ecotoxicological parameters. The use of biomass fly ashes has reduced significantly the $\mathrm{Pb}$ concentration in the synthetic wastewater and in the wastewaters collected in the IWWTP. For example, the definitive coagulation-flocculation assays performed over the IWWTP effluent presented a very low concentration of $\mathrm{Pb}(0.35 \mathrm{mg} / \mathrm{L})$ for the $\mathrm{S} / \mathrm{L}$ ratio of $1.23 \mathrm{~g} / \mathrm{L}$. Globally, the ecotoxicological characterization of the supernatants resulting from the coagulation-flocculation assays of all wastewaters has indicated an overall reduction on the ecotoxicity of the crude wastewaters, due to the removal of $\mathrm{Pb}$.
\end{abstract}

(c) 2014 Elsevier Inc. All rights reserved.

\section{Introduction}

The most common sources of lead in the environment are $\mathrm{Pb}$ based pigments in paints, $\mathrm{Pb}$-containing pesticides, discarded batteries, shooting ranges or waterfowl hunting sites and plumbing installations or repair sites [1]. Despite some efforts on the reduction of the use of lead in some industrial activities and in some manufactured products, there are still some industries that use lead as raw material. Since lead is a heavy metal which is toxic to humans and to other living beings it is extremely important to remove this pollutant from wastewater [2-5].

The precipitation of metals from wastewaters involves the conversion of the soluble metal salt to insoluble salts [6,7]. The precipitate formed can then be removed from the treated wastewater by sedimentation and/or filtration. This process usually needs a $\mathrm{pH}$ adjustment, followed by the addition of a chemical coagulant [812 ]. Typically, metals precipitate from the solution as hydroxides, sulfides or carbonates. Depending on the type of the process used, it may be produced a sludge with so high concentrations of metals

\footnotetext{
* Corresponding author. Fax: +351 212948543.

E-mail addresses: rfb@fct.unl.pt, r_p_f_b@hotmail.com (R. Barbosa).
}

that can be submitted to metal recovery $[13,14]$. The classical wastewater treatment systems use ferric-chloride, ferric-sulfate and aluminum sulfate as coagulation reagents, but due to their high cost, the industrial sector has begun to search for efficient and low cost chemical agents.

In this framework, several studies have been performed related to wastewater treatment using fly ashes produced from the combustion of several fuels $[6,10,12,15-19]$. However, these studies were not focused neither on the treatment of wastewaters produced by industries of lead-acid batteries nor on the use of biomass fly ashes from forestry residues as chemical agents for metal removal.

Coal fly ashes have a high potential in the treatment of wastewater because of their chemical composition. This type of fly ashes has high contents of alumina, silica, ferric oxide, calcium oxide, magnesium oxide and carbon, which can participate on the removal of several elements [6,7]. Moreover, the physical properties of coal fly ashes, such as porosity, particle size distribution and surface area, make them also attractive for the treatment of wastewaters. The alkaline nature of fly ashes is also a useful property which make them a good neutralizing agent of acid wastewaters [8,9].

$\mathrm{Al}$ Zboon et al. [12] have produced a geopolymer from coal fly ashes and used it for the removal of $\mathrm{Pb}^{2+}$ from an aqueous 